\begin{tabular}{|c|c|c|}
\hline deCartesian $\mathbf{e}$ & Jurnal Matematika dan Aplikasi & \\
\hline & deOaretesiaI & \\
\hline$=-1 \mathrm{IIII}$ & $\begin{array}{c}\text { ISSN:2302-4224 } \\
\text { J o u r n a I h o m e p a g e: } \mathrm{https://ejournal.unsrat.ac.id/index.php/decartesian}\end{array}$ & deCartesian \\
\hline
\end{tabular}

\title{
Analisis Prediksi IHSG Berdasarkan Kurs Beli IDR-USD Melalui Regresi Copula
}

\author{
Nia Lestari Arisandi ${ }^{1}$, Didit Budi Nugroho ${ }^{1}$, Leopoldus Ricky Sasongko ${ }^{{ }^{*}}$ \\ ${ }^{1}$ Program Studi Matematika-Fakultas Sains dan Matematika-Universita Kristen Satya Wacana, Jln. Diponegoro No. 52-60, \\ Salatiga 50711, Indonesia \\ *Corresponding author : leopoldus.sasongko@staff.uksw.edu.
}

\section{A B S T RA K}

Analisis prediksi merupakan langkah penting yang perlu dilakukan untuk menganalisis suatu model prediksi. Suatu model prediksi ditentukan untuk suatu tujuan guna memperoleh perkiraan nilai dari suatu pengamatan di masa depan. Pada umumnya, model prediksi diperoleh melalui metode regresi. Dalam paper ini, model prediksi yang dibahas adalah model yang diperoleh melalui metode regresi dan yang melibatkan fungsi yang disebut copula (bivariat), yang kemudian model ini disebut model regresi copula. Copula merupakan suatu fungsi distribusi gabungan yang dapat digunakan untuk menganalisis kebergantungan peubah-peubah acak dalam struktur yang digambarkan oleh fungsi copula itu sendiri. Fungsi-fungsi copula yang variatif mampu memberikan banyak pilihan model-model regresi copula. Data yang dikaji dalam paper ini adalah data return IHSG dan return Kurs Beli IDR-USD, yang kemudian kedua data tersebut dimodelkan melalui model regresi copula. Ukuran kebergantungan kedua data return dapat dinyatakan oleh Kendall's Tau dan Spearman's Rho. Parameter yang dimiliki copula diestimasi melalui nilai Kendall's Tau atau Spearman's Rho yang diperoleh dari kedua data return sehingga tiap copula memiliki kemungkinan untuk memodelkan kedua data return berdasarkan parameter yang telah diestimasi dari cara tersebut. Model regresi copula diperoleh dari ekspektasi bersyarat yang dimiliki copula untuk peubah return IHSG bergantung pada peubah return Kurs Beli IDR-USD yang mana perolehan nilai prediksi return IHSG yang bergantung pada nilai return Kurs Beli IDR-USD dihitung dengan menggunakan metode Monte Carlo. Model regresi copula terbaik dari hasil pembahasan dalam paper ini adalah model regresi copula Frank dengan distribusi marginal return IHSG adalah distribusi Laplace dan marginal return Kurs beli IDR-USD adalah distribusi Normal. Model regresi copula Frank tersebut terpilih menjadi yang terbaik berdasarkan dari error nilai prediksi terhadap data return IHSG yang bergantung pada return Kurs Beli IDR-USD relatif kecil dibandingkan dengan model regresi copula lain yang dibahas dalam paper ini.
\end{abstract}

\section{INFO ARTIKEL}

Diterima : 23 April 2018

Diterima setelah revisi : 9 Mei 2018

Tersedia online $\quad$ : 30 Juli 2018

\section{Kata Kunci :}

Prediksi,

Copula,

Ukuran Kebergantungan,

Kurs dan IHSG,

Monte Carlo.

\section{PENDAHULUAN}

Indeks harga saham gabungan (IHSG) merupakan suatu indikator yang dapat menggambarkan perkembangan harga saham secara keseluruhan di Indonesia. IHSG dapat menggambarkan keadaan dan stabilitas perekonomian Indonesia. Menurut [1] faktor-faktor yang dapat mempengaruhi kenaikan atau penurunan IHSG adalah peubah-peubah makroekonomi seperti nilai tukar mata uang atau kurs, tingkat suku bunga, tingkat inflasi, serta berbagai regulasi dan deregulasi ekonomi.
Kurs rupiah terhadap valuta asing (valas) adalah perbandingan nilai mata uang rupiah terhadap nilai mata uang negara lain. Kurs rupiah terhadap valas menjadi salah satu faktor yang mempengaruhi volatilitas return harga saham-saham di BEI. Fluktuasi harga saham suatu perusahaan emiten BEI yang disebabkan oleh penguatan atau pelemahan kurs rupiah terhadap valas tentu mempengaruhi IHSG. Secara tidak langsung, penguatan atau pelemahan kurs rupiah terhadap valas memiliki pengaruh terhadap kenaikan atau penurunan IHSG sehingga analisis hubungan kedua hal tersebut penting untuk diteliti. 
Kebergantungan dua peubah dapat dijelaskan melalui metode regresi. Melalui regresi pula, prediksi pada suatu peubah dapat dilakukan berdasarkan peubah lain. Analisis regresi yang dapat digunakan salah satunya adalah analisis regresi copula. Copula merupakan suatu fungsi distribusi gabungan yang dapat digunakan untuk menganalisis kebergantungan peubah-peubah acak dalam struktur yang digambarkan oleh fungsi copula itu sendiri, sehingga analisis prediksi suatu peubah terhadap peubah yang lain dapat dilakukan melalui regresi copula (copula regression). Model regresi copula dapat ditentukan melalui metode ekspektasi bersyarat berbasis copula. Melalui model regresi copula, analisis prediksi peubah satu terhadap peubah yang lain dapat dilakukan.

Paper ini membahas IHSG dan kurs beli IDR (Indonesian Rupiah) terhadap valas sebagai peubah-peubah yang memiliki kebergantungan satu terhadap yang lain. Valuta asing yang menjadi acuan dalam penelitian adalah USD (United States Dollar) karena sebagian besar aktivitas perdagangan internasional Indonesia merupakan kerjasama dengan Amerika (United States of America) sehingga kurs beli IDR-USD adalah kurs yang sering menjadi patokan dalam menilai perekonomian Indonesia. Copula berperan sebagai fungsi distribusi gabungan dari IHSG dan kurs beli IDR-USD. Analisis prediksi IHSG berdasarkan kurs beli IDR-USD dilakukan dengan melibatkan model regresi copula. Data pengamatan yang digunakan dalam paper ini adalah data IHSG dan kurs beli IDR-USD dalam rentang waktu selama dua tahun dari bulan Juli 2015 hingga Juni 2017.

Beberapa penelitian sebelumnya telah membahas tentang copula baik dalam mencari kebergantungan antar dua peubah maupun melakukan prediksi. Salah satu penelitiannya dilakukan oleh Darwis [2], yang membahas tentang analisis hubungan dan prediksi IHSG dengan menggunakan faktor makroekonomi melalui pendekatan copula. Faktor makroekonomi yang digunakan meliputi tiga jenis yaitu Inflasi, Nilai Tukar, dan Suku Bunga. Dalam pendugaan parameternya Darwis menggunakan pendekatan Kendall's tau. Selain Darwis, Oktavina [3] juga membahas penelitian tentang copula yaitu tentang model prediksi berbasis copula. Berbeda dengan Darwis [2], Oktavina [3] menggunakan 3 jenis ukuran kebergantungan yaitu Pearson's Correlation Coefficient, Kendall's Tau, dan Spearman's Rho.

Tujuan dari dilakukannya paper ini adalah memperoleh model prediksi IHSG berdasarkan kurs beli IDR-USD melalui regresi copula. Setelah memperoleh model prediksi IHSG maka dilakukan analisis prediksi IHSG berdasarkan kurs beli IDR-USD.

\section{Stasioneritas}

Stasioner mempunyai arti tidak adanya perubahan drastis pada data. Data dapat dinyatakan stasioner apabila mempunyai rata-rata dan variansi yang konstan. Jika data tidak stasioner maka harus dilakukan proses transformasi data agar diperoleh data yang stasioner. Pengujian stasioneritas data dapat dilakukan dengan mengamati plot data time series maupun dapat dilihat dari nilai autocorrelation pada plot Autocorrelation Function (ACF).

\section{Transformasi Data}

Dalam suatu analisis apabila data yang digunakan tidak stasioner maka harus dilakukan transformasi data sehingga data menjadi stasioner. Transformasi data merupakan proses mengubah skala data asli menjadi skala yang berbeda sehingga data bisa memenuhi asumsi yang mendasari analisis dengan begitu data siap untuk dianalisis. Salah satu transformasi data yang sering digunakan dalam analisis bidang keuangan adalah transformasi return. Untuk melakukan transformasi return dapat dilakukan dengan persamaan

$$
\begin{aligned}
x_{t} & =-\ln \frac{\operatorname{Kurs}_{t}}{\operatorname{KurS}_{t-1}} \\
y_{t} & =\ln \frac{I H S G_{t}}{I H S G_{t-1}}
\end{aligned}
$$

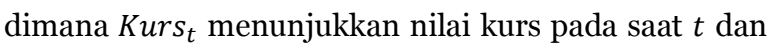
$I H S G_{t}$ menunjukkan IHSG pada saat $t$.

\section{Ukuran Kebergantungan Data Bivariat}

Berdasarkan [1] salah satu faktor yang mempengaruhi terjadinya fluktuasi IHSG adalah Kurs, maka untuk mengetahui hubungan antara IHSG dan Kurs digunakan dua jenis ukuran kebergantungan yaitu Kendall's rank correlation dan Spearman's rank correlation.

Berdasarkan [4] Kendall's rank correlation adalah ukuran kebergantungan dua peubah yang diperoleh dari selisih antara peluang concordant dengan peluang discordant. Misalkan c menunjukkan jumlah pasangan yang concordant dan d menunjukkan jumlah pasangan yang discordant, maka Kendall's tau untuk sampel sebanyak $n$ didefinisikan oleh

$$
\tau=\frac{c-d}{c+d}=(c-d) /\left(\begin{array}{l}
n \\
2
\end{array}\right)
$$

Sedangkan, Spearman's rho dapat diperoleh dengan menghitung selisih antara probabilitas concordant dengan probabilitas discordant. Untuk semua $n$ bilangan bulat yang berbeda dan menyatakan peringkat data, Spearman's rho dapat dihitung melalui persamaan

$$
\rho=1-\frac{6 \sum d_{i}^{2}}{n\left(n^{2}-1\right)}
$$

di mana $d_{i}=\operatorname{rank}\left(x_{i}\right)-\operatorname{rank}\left(y_{i}\right)$ adalah perbedaan antara dua peringkat dari setiap pengamatan.

\section{Goodness of Fit Test}

Uji Goodness of fit menjadi bagian penting dalam paper ini, karena digunakan untuk pendugaan parameter IHSG dan Kurs Beli IDR-USD. Ini dikarenakan Uji Goodness of fit dapat mengukur tingkat kesesuaian antara suatu distribusi data penelitian 
dengan suatu distribusi data tertentu. Langkah-langkah dalam Uji Goodness of fit adalah dengan melakukan estimasi parameter distribusi dan uji kecocokan distribusi melalui metode teoritis tertentu. Estimasi parameter distribusi dilakukan dengan metode Maximum

Likelihood Estimation (MLE) yang dapat dilihat pada [5], sedangkan untuk uji kecocokan distribusi dilakukan dengan metode Kolmogorov-Smirnov yang dapat dilihat pada [5].

\section{Copula}

Menurut [4] Copula (bivariat) merupakan fungsi distribusi bivariat dengan marginal-marginalnya berdistribusi seragam di $[0,1]$. Secara matematis copula $C$ dinyatakan oleh

$$
C(u, v)=\operatorname{Pr}[U \leq u, V \leq v]
$$

Misalkan dua peubah acak kontinu $X$ dan $Y$ memiliki fungsi distribusi berurutan $F$ dan $G$, maka dapat dibentuk peubah acak baru yaitu $U=F(X)$ dan $V=G(Y)$. Berdasarkan teorema Sklar [4] fungsi distribusi bivariat $X$ dan $Y$ didefinisikan oleh

$$
\begin{aligned}
H(x, y) & =\operatorname{Pr}[X \leq x, Y \leq y] \\
& =\operatorname{Pr}[F(X) \leq F(x), G(Y) \leq G(y)] \\
& =\operatorname{Pr}[U \leq u, V \leq v] \\
& =C(u, v)
\end{aligned}
$$

untuk suatu copula $C$. Jika $H$ adalah fungsi distribusi bivariat dengan fungsi distribusi marginal (margin) $F$ dan $G$, maka terdapat suatu copula $C$ untuk semua $(x, y)$ sedemikian hingga

$$
H(x, y)=C(F(x), G(y))
$$

Fungsi kepadatan peluang atau p.d.f (probability density function) bivariat yang berkorespondensi dengan copula $C$ dapat dinyatakan dalam

$$
h(x, y)=f(x) g(y) c(F(x), G(y))
$$

dimana

$$
c(u, v)=\frac{\partial^{2} C(u, v)}{\partial u \partial v}
$$

adalah fungsi densitas copula, dengan $c(u, v)=1$, jika $X$ dan $Y$ saling bebas begitu pula sebaliknya.

Berdasarkan [4], ukuran kebergantungan antara dua peubah acak yang berkaitan dengan copula $C$ yaitu Kendall's tau $(\tau)$ dan Spearman's rho $(\rho)$. Kendall's tau dalamkaitannya dengan copula $C$ didefinisikan oleh

$$
\tau=4 \iint_{I^{2}} C(u, v) d C(u, v)-1
$$

Sedangkan Spearman's rho untuk $X$ dan $Y$ dalam kaitannya dengan copula $C$ berdasarkan [4] didefinisikan oleh

$$
\rho=12 \iint_{I^{2}} C(u, v) d u d v-3
$$

Selanjutnya akan dijelaskan properti bersyarat yang kaitannya dengan copula meliputi fungsi densitas peluang bersyarat, fungsi distribusi bersyarat, dan ekspektasi bersyarat berdasarkan pada [4].

Fungsi densitas peluang $Y=y$ bersyarat $X=x$ yaitu $k(y \mid x)$ dan dalam kaitannya dengan copula berdasarkan [6] adalah

$$
\begin{array}{r}
k(y \mid x)=\operatorname{Pr}[Y=y \mid X=x]=\frac{\operatorname{Pr}[X=x, Y=y]}{\operatorname{Pr}[X=x]} \\
=\frac{h(x, y)}{f(x)} \\
=\frac{c(F(x), G(y)) f(x) g(y)}{f(x)}= \\
c(F(x), G(y)) g(y)
\end{array}
$$

lalu fungsi distribusi $Y$ bersyarat $X=x$ yaitu $K(y \mid x)$ dan dalam kaitannya dengan copula diperoleh dari

$$
\begin{aligned}
K(y \mid x) & =\operatorname{Pr}[Y \leq y \mid X \leq x]=\int_{-\infty}^{y} k(y \mid x) d y \\
& =\int_{-\infty}^{y} c(F(x), G(y)) g(y) d y
\end{aligned}
$$

sedangkan ekspektasi peubah acak $Y$ bersyarat $X=x$ kaitannya dengan copula adalah

$$
\begin{aligned}
E[Y \mid X=x] & =\int_{-\infty}^{\infty} y k(y \mid x) d y \\
& =\int_{-\infty}^{\infty} y c(F(x), G(y)) g(y) d y
\end{aligned}
$$

Karena $G(y)=v$ dan $g(y) d y=d v$, ekspektasi peubah acak $Y$ bersyarat $X=x$, untuk $u=F(x)$, dapat dituliskan sebagai

$$
E[Y \mid X=x]=\int_{0}^{1} G^{-1}(v) c(u, v) d v
$$

\subsection{Copula Archimedean}

Keluarga copula Archimedean memiliki kekhasan bahwa suatu copula memiliki satu parameter kebergantungan $(\theta)$ dan dapat dibentuk dari suatu fungsi pembangkit copula $\varphi$. Copula Archimedean untuk peubah acak bivariat didefinisikan sebagai

$$
C_{\theta}(u, v)=\varphi^{-1}(\varphi(u)+\varphi(v))
$$

Berdasarkan (9) estimasi parameter copula Archimedean $(\theta)$ dengan Kendall's tau $(\tau)$ dapat diperoleh dengan mencari solusi persamaan berikut ini

$$
\tau=1+4 \int_{0}^{1} \frac{\varphi_{\theta}(t)}{\varphi_{\theta}^{\prime}(t)} d t
$$

seperti pada [4]. Dalam paper ini digunakan empat jenis copula Archimedean yang dijelaskan berdasarkan [4].

Fungsi copula Clayton didefinisikan oleh

$$
C_{C, \theta}(u, v)=\left(u^{-\theta}+v^{-\theta}-1\right)^{-\frac{1}{\theta}}
$$

dengan $\theta \in(0, \infty)$. Fungsi pembangkit copula Clayton diberikan oleh

$$
\varphi_{\theta}(t)=\frac{1}{\theta}\left(t^{-\theta}-1\right)
$$


Fungsi densitas copula Clayton diperoleh dari solusi persamaan (8), yang didefinisikan oleh

$$
c_{C, \theta}(u, v)=\frac{\theta+1}{(u v)^{\theta+1}}\left(u^{-\theta}+v^{-\theta}-1\right)^{-\left(\frac{2 \theta+1}{\theta}\right)}
$$
oleh

Properti bersyarat copula Clayton didefinisikan

$$
\frac{\partial C_{C, \theta}(u, v)}{\partial u}=u^{-(\theta+1)}\left(u^{-\theta}+v^{-\theta}-1\right)^{-\left(\frac{\theta+1}{\theta}\right)}
$$

Parameter $\theta$ copula Clayton diperoleh dari persamaan (16) dengan mensubstitusikan persamaan (18) yaitu

$$
\theta=\frac{2 \tau}{1-\tau}
$$

Fungsi copula Gumbel didefinisikan oleh

$$
C_{G, \theta}(u, v)=\exp \left(-\left[(-\ln u)^{\theta}+(-\ln v)^{\theta}\right]^{\frac{1}{\theta}}\right)
$$

dengan $\theta \in[1, \infty)$. Fungsi pembangkit copula Gumbel adalah

$$
\varphi_{\theta}(t)=(-\ln t)^{\theta}
$$

Fungsi densitas copula Gumbel menurut [7] dapat diperoleh dari persamaan (8) yaitu

$c_{G, \theta}(u, v)=(u v)^{-1}(\ln u \cdot \ln v)^{\theta-1}$

$$
\cdot\left(w^{\frac{2}{\theta}-2}+(\theta-1) w^{\frac{1}{\theta}-2}\right) C_{G, \theta}(u, v)
$$

Properti bersyarat copula Gumbel didefinisikan oleh

$$
\frac{\left(-\ln (u)^{\theta}-\ln (v)^{\theta}\right)^{\frac{1}{\theta}} \ln (u)^{\theta} e^{-\left(-\ln (u)^{\theta}-\ln (v)^{\theta}\right)^{\frac{1}{\theta}}}}{u \ln (u)\left(-\ln (u)^{\theta}-\ln (v)^{\theta}\right)}
$$

Parameter $\theta$ copula Gumbel diperoleh melalui solusi persamaan (16) dengan mensubstitusikan persamaan (23) adalah

$$
\theta=\frac{1}{1-\tau}
$$

Fungsi copula Frank didefinisikan oleh

$$
C_{F, \theta}(u, v)=-\frac{1}{\theta} \ln \left(1+\frac{\left(e^{-\theta u}-1\right)\left(e^{-\theta v}-1\right)}{e^{-\theta}-1}\right)
$$

dengan $\theta \in(-\infty, \infty)$. Fungsi pembangkit copula Frank adalah

$$
\varphi_{\theta}(t)=-\ln \left(\frac{e^{-\theta t}-1}{e^{-\theta}-1}\right)
$$

Fungsi densitas copula Frank menurut [8] diperoleh dari persamaan (8) yang didefinisikan oleh

$$
c_{F, \theta}(u, v)=\frac{-\theta e^{-\theta(u+v)}\left(e^{-\theta}-1\right)}{\left(e^{-\theta}-1+\left(e^{-\theta u}-1\right)\left(e^{-\theta v}-1\right)\right)^{2}}
$$
oleh

Properti bersyarat copula Frank didefinisikan

$$
\frac{\partial C_{F, \theta}(u, v)}{\partial u}=\frac{\left(e^{-\theta v}-1\right)}{e^{\theta v}\left(e^{-\theta}-1\right)\left(\frac{\left(e^{\theta v}-1\right)\left(e^{\theta v}-1\right)}{\left(e^{-\theta}-1\right)}+1\right)}
$$

Solusi persamaan (16) diselesaikan dengan mensubstitusikan persamaan (28), diperolah parameter $\theta$ copula Frank adalah

$$
\tau=1-\frac{4\left(1-\theta^{-1} \int_{0}^{\theta} \frac{t}{e^{t}-1} d t\right)}{\theta}
$$

Copula AMH (Ali-Mikhail-Haq) dinyatakan oleh

$$
C_{A, \theta}=\frac{u v}{1-\theta(1-u)(1-v)}
$$

dengan $\theta \in[-1,1)$. Fungsi pembangkit copula $\mathrm{AMH}$ adalah

$$
\varphi_{\theta}(t)=\ln \left[\frac{1-\theta(1-t)}{t}\right]
$$

Fungsi densitas copula AMH berdasarkan [9] dapat diperoleh dari persamaan (8) yang berbentuk

$$
c_{A, \theta}(u, v)=\frac{1-\theta+2 \theta \frac{u v}{1-\theta(1-u)(1-v)}}{[1-\theta(1-u)(1-v)]^{2}}
$$

Properti bersyarat copula AMH didefinisikan ditunjukkan oleh persamaan berikut ini:

$$
\frac{v}{1-\theta(1-u)(1-v)}-\frac{u}{(1-\theta(1-u)(1-v))^{2}}
$$

Persamaan (16) diselesaikan dengan mensubstitusikan persamaan (33), diperoleh Kendall's tau copula AMH yang dinyatakan oleh

$$
\tau=\frac{3 \theta-2}{3 \theta}-\frac{2(1-\theta)^{2} \ln (1-\theta)}{3 \theta^{2}}
$$

Estimasi parameter $\theta$ dari copula AMH diperoleh dengan menyelesaikan persamaan (36) dengan menggunakan metode numerik.

\subsection{Copula Plackett}

Copula Plackett mempunyai bentuk umum yang didefinisikan oleh

$$
\begin{aligned}
C_{\mathrm{P}, \theta}(u, v) & =\frac{[1+(\theta-1)(u+v)]}{2(\theta-1)} \\
& -\frac{\sqrt{[1+(\theta-1)(u+v)]^{2}-4 u v \theta(\theta-1)}}{2(\theta-1)}
\end{aligned}
$$

di mana $0<\theta<\infty$ dan $\theta \neq 1$. Saat $\theta=1, C_{\mathrm{P}, 1}(u, v)=$ $u v$.

Fungsi densitas copula Plackett diperoleh dari persamaan (8) seperti yang dijelaskan pada [10], sehingga dipeorleh

$$
c_{\mathrm{P}, \theta}(u, v)=\frac{\theta[1+(\theta-1)(u+v-2 u v)]}{\left[(1+(\theta-1)(u+v))^{2}-4 u v \theta(\theta-1)\right]^{\frac{3}{2}}}
$$

Properti bersyarat copula Gumbel didefinisikan oleh

$$
\frac{\partial C_{\mathrm{P}, \theta}(u, v)}{\partial u}=\frac{\theta v-(\theta-1) C_{\mathrm{P}, \theta}(u, v)}{1+(\theta-1)\left[u+v-2 C_{\mathrm{P}, \theta}(u, v)\right]}
$$

Berdasarkan [4], diperoleh Spearman's rho melalui copula Plackett yang dinyatakan oleh

$$
\rho=\frac{\theta+1}{\theta-1}-\frac{2 \theta}{(\theta-1)^{2}} \ln \theta
$$

Estimasi parameter $\theta$ copula Plackett dilakukan dengan mencari solusi persamaan (40) dengan menggunakan metode bagi dua seperti yang dijelaskan pada [11].

\subsection{Simulasi Pembangkitan Bilangan Acak Bivariat Menggunakan Copula \\ Menurut [6] prosedur untuk membangkitkan} bilangan acak bivariat $\{(x, y)\}$ dari suatu fungsi distribusi bivariat $H$ dapat dilakukan dengan menggunakan 
copula. Misalkan fungsi $\frac{\partial C(u, v)}{\partial u}$ adalah fungsi dalam $v$, misal $u=F(x)$ dan $v=G(y)$,

$$
z_{u}(v)=\frac{\partial C(u, v)}{\partial u}
$$

Prosedur pembangkitan bilangan acak bivariat $\{(x, y)\}$ dapat dilakukan dengan langkah berikut:

- Langkah pertama dilakukan dengan membangkitkan dua bilangan acak saling bebas $u$ dan $t$, dimana $u$ dan $t$ berdistribusi seragam di $[0,1]$;

- Langkah kedua dengan menghitung $v=z_{u}{ }^{(-1)}(t)$, dimana $z_{u}{ }^{(-1)}$ adalah invers fungsi dari $z_{u}$;

- Pada langkah ketiga ini dapatkan sepasang bilangan acak bivariat dari suatu copula yaitu $(u, v)$;

- Langkah keempat dapatkan sepasang bilangan acak bivariat $(x, y)=\left(F^{-1}(u), G^{-1}(v)\right)$;

\section{Metode Monte Carlo}

Metode Monte Carlo diperlukan sebagai pendekatan numerik yang digunkana untuk menemukan solusi dari suatu persamaan. Misal, diketahui bahwa

$$
\int_{0}^{1} h(x) d x
$$

dimana $X$ adalah peubah acak yang seragam di $[0,1]$. Maka fungsi densitas diberikan oleh $f(x)=1$ untuk $0<x<1$. Sehingga,

$$
E_{f}[h(X)]=\int_{0}^{1} h(x) d x=\alpha
$$

Pada simulasi dengan menggunakan komputer, dapat dilakukan dengan membangkitkan nilai numerik. Sehingga solusi pendekatan persamaan (42) diperoleh dengan menghitung nilai rata-rata dari $\left\{h\left(X_{i}\right) \mid i=1, \ldots, n\right\}$.

\section{Ukuran Ketepatan Nilai Prediksi}

Menentukan kesalahan prediksi dapat diukur menggunakan berbagai ukuran error, dimana diketahui bahwa $\hat{y}_{t}$ adalah data prediksi dari perhitungan model pada waktu $t, y_{t}$ adalah data aktual pada waktu $t$ dan $\mathrm{n}$ adalah banyaknya data. Beberapa ukuran error yang digunakan dalam menghitung nilai ketepatan prediksi pada paper ini, yaitu

Mean Square Error (MSE) dapat dihitung dengan persamaan:

$$
M S E=\frac{1}{n} \sum_{i=1}^{n}\left(\hat{y}_{t}-y_{t}\right)^{2}
$$

Mean Error (ME) dapat dihitung dengan persamaan:

$$
M E=\sum_{i=1}^{n} \hat{y}_{t}-y_{t}
$$

Root Mean Square Error (RMSE) dapat dihitung dengan persamaan:

$$
R M S E=\sqrt{M S E}=\sqrt{\frac{\sum_{i=1}^{n}\left(\hat{y}_{t}-y_{t}\right)^{2}}{n}}
$$

Mean Absolute Error (MAE) dapat dihitung dengan persamaan:

$$
M A E=\frac{1}{n} \sum_{i=1}^{n}\left|\hat{y}_{t}-y_{t}\right|
$$

\section{Metode Bagi Dua}

Metode bagi dua digunakan dalam penyelesaian solusi estimasi parameter copula pada persamaan (36). Berdasarkan pada [11] untuk melakukan metode bagi dua dapat dilakukan dengan mengikuti Algoritma berikut ini:

- Pertama hitunglah $\theta_{n}=\frac{a_{n}+b_{n}}{2}$.

- Kedua tentukalahn subinterval mana yang akan mengurung akar:

a. Jika $f\left(a_{n}\right) \cdot f\left(\theta_{n}\right)<0$, maka $a_{n+1}=a_{n}, b_{n+1}=\theta_{n}$.

b. Jika $f\left(a_{n}\right) \cdot f\left(\theta_{1}\right)>0$, maka $a_{n+1}=\theta_{n}, b_{n+1}=b_{n}$.

c. Jika $f\left(a_{n}\right) \cdot f\left(\theta_{1}\right)=0$, maka diperoleh akar sama dengan $\theta_{n}$.

- Ketiga hitunglah $\varepsilon_{n}=\frac{\theta_{n}-\theta_{n-1}}{\theta_{n}} \times 100 \%$ dimana $n \geq 1$

- Selanjutnya ulangi langkah 1 hingga langkah 3 sedemikian sehingga diperoleh nilai $f\left(\theta_{n}\right) \approx 0$.

- Kelima, diperoleh akar persamaan yaitu $\theta_{n}$.

\section{Metode Penelitian}

Disini dilakukan pengolahan data yang dimiliki melalui langkah-langkah berikut:

1. Data dibagi menjadi dua yaitu bagian I (Juli 2015 sampai Juni 2016) dan bagian II (Juli 2016 sampai Juni 2017). Data bagian I digunakan untuk mencari model prediksi, sedangkan data bagian II digunakan untuk validasi prediksi.

2. Transformasi data (bagian I) menggunakan transformasi return pada persamaan (1) dan (2), sehingga diperoleh data bivariat $\left(x_{t}, y_{t}\right)$. Uji stasioneritas dilakukan secara visual dan dibantu dengan grafik ACF (Autocorrelation Function).

3. Mengukur kebergantungan data hasil transformasi dengan menggunakan ukuran kebergantungan Kendall's tau dan Spearman's rho.

Setelah dilakukan pengolahan data, langkah selanjutnya adalah analisis data berdasarkan pada langkah-langkah berikut:

1. Estimasi parameter distribusi-distribusi marginal $x_{t}$ dan $y_{t}$ dilakukan dengan Maximum Likelihood Estimation (MLE).

2. Uji kecocokan distribusi $x_{t}$ dan $y_{t}$ menggunakan metode Kolmogorov-Smirnov.

3. Estimasi parameter $\theta$ copula Archimedean berdasarkan Kendall's tau dan estimasi parameter $\theta$ copula Plackett berdasarkan Spearman's rho. 
4. Analisis regresi copula menggunakan ekspektasi bersyarat pada persamaan (13) untuk memperoleh $\hat{y}_{i}$, dimana analisis regresi copula dihitung menggunakan metode Monte Carlo yang dibangkitkan dengan algoritma
a. Untuk $i=1$ tetapkan $u_{i}$ dimana $u_{i}=F\left(x_{i}\right)$;
b. Bangkitkan $v_{j}$ sebanyak 1000 data melalui copula;
c. Hitung nilai dari $\hat{y}_{i}$
d. Ulangi langkah b dan c sebanyak 1000 kali;
e. Hitung rata-rata dari $\hat{y}_{i}$;
f. Untuk $i=i+1$ kembali ke langkah a.

5. Estimasi copula berdasarkan beberapa ukuran error (MSE, MAE, ME, RMSE) dengan mencari nilai error terkecil.

6. Validasi prediksi melalui model regresi copula terpilih berdasarkan ukuran error.

\section{HASIL DAN PEMBAHASAN}

\section{1. Data Marginal}

Setelah dilakukan pengolahan data, diperoleh data hasil transformasi return yang sudah stasioner. Data yang sudah stasioner dari $x_{t}$ (return Kurs Beli IDR-USD) dan $y_{t}$ (return IHSG) disajikan pada Gambar 1.

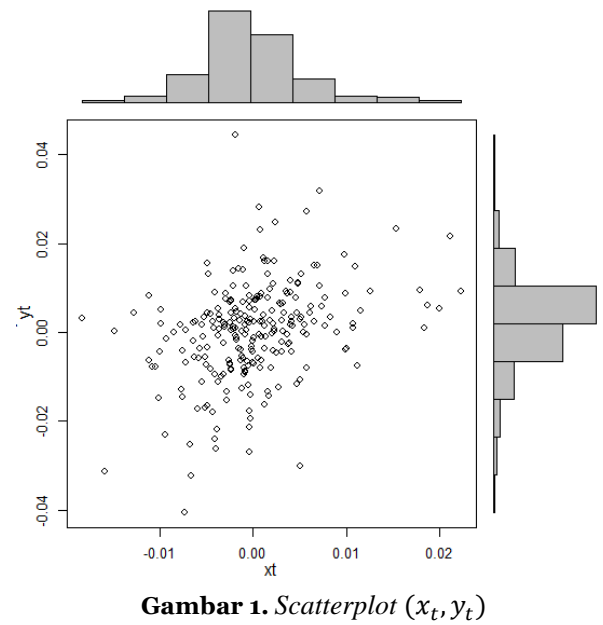

Gambar 1 merupakan scatterplot $\left(x_{t}, y_{t}\right)$ data bagian I dari $x_{t}$ (return Kurs Beli IDR-USD) dan $y_{t}$ (return IHSG)yang sudah stasioner. Histogram masingmasing marginal $x_{t}$ dan $y_{t}$ ditampilkan sebelah atas $\left(x_{t}\right)$ dan kanan $\left(y_{t}\right)$ scatterplot pada Gambar 1. Selanjutnya dicari statistik deskriptif dari $x_{t}$ dan $y_{t}$ yang disajikan pada tabel 1.

Tabel 1. Statistik Deskriptif

\begin{tabular}{ccccccc}
\hline & Mean & Var. & Kurtosis & Skewness & Min. & Maks. \\
\hline$x_{t}$ & $4 E-05$ & $\begin{array}{c}3.6 E \\
-05\end{array}$ & 2.1103 & 0.65546 & -0.018 & 0.0222 \\
\hline$y_{t}$ & $8 E-05$ & 0.00012 & 2.0128 & -0.17313 & -0.040 & 0.0445
\end{tabular}

Tabel 1 merupakan statistik deskriptif dari masing-masing peubah acak $x_{t}$ dan $y_{t}$, dari tabel 1 dapat dilihat bahwa nilai dari kurtosis dan skewness untuk setiap peubah acak $x_{t}$ dan $y_{t}$ tidak berdistribusi normal. Data dapat dikatakan berdistribusi normal jika nilai dari kurtosis sama dengan tiga dan nilai dari skewness sama dengan nol.

\section{2. Ukuran Kebergantungan}

Ukuran kebergantungan Kendall's tau dan Spearman's rho data $x_{t}$ dan $y_{t}$ tertampil di Tabel 2.

Tabel 2. Ukuran Kebergantungan Kendall's tau dan Spearman's rho dari Data Marginal $x_{t}$ dan $y_{t}$

\begin{tabular}{c|c|c}
\hline Peubah & Kendall's tau & Spearman's rho \\
\hline$x_{t}$ dan $y_{t}$ & 0.241 & 0.3550996 \\
\hline
\end{tabular}

\section{3. Estimasi Parameter Distribusi Marginal} dan Uji Kecocokan Distribusi

Estimasi parameter distribusi marginal dilakukan dengan mengestimasi parameter-parameter yang bersesuaian (melalui MLE) dan uji kecocokan distribusi melalui metode Kolmogorov-Smirnov ( $p$-value). Dari hasil estimasi parameter distribusi marginal berdasarkan data $x_{t}$ dan $y_{t}$ diperoleh beberapa pilihan parameter distribusi yang sesuai, yang disajikan pada Tabel 3 .

Tabel 3. Parameter dan Uji Kecocokan Kolmogorov-Smirnov (p-value) Distribusi Marginal Data

\begin{tabular}{ccccc}
\hline Dist. & Marg. & \multicolumn{2}{c}{ Parameter } & $p$-value (KS) \\
\hline Logistik & & $\sigma=0.00332$ & $\mu=0.00004$ & 0.22152 \\
Laplace. & \multirow{2}{*}{$x_{t}$} & $\lambda=235.17$ & $\mu=0.00004$ & 0.21525 \\
Normal & & $\sigma=0.00601$ & $\mu=0.00004$ & 0.07222 \\
\hline Logistik & & $\sigma=0.00609$ & $\mu=0.00008$ & 0.17777 \\
Laplace. & $y_{t}$ & $\lambda=128.11$ & $\mu=0.00008$ & 0.15000 \\
Normal & & $\sigma=0.11044$ & $\mu=0.00008$ & 0.15000 \\
\hline
\end{tabular}

Berdasarkan Tabel 3, untuk setiap marginal $x_{t}$ dan $y_{t}$ mempunyai tiga pilihan distribusi yang dapat digunakan dalam menentukan model prediksi. Hal ini dikarenakan hipotesa $H_{0}$ dari ketiga distribusi tersebut diterima di tingkat signifikansi 0.05 atau nilai $p$-value $>$ 0.05. Copula Archimedean (Clayton, Gumbel, Frank, dan $\mathrm{AMH}$ ) dan copula Plackett selanjutnya diestimasi untuk kombinasi marginal

$x_{t}:$ Logistik, Laplace, Normal; dan

$y_{t}$ : Logistik, Laplace, Normal.

Dari sini, dicari distribusi marginal paling sesuai yang selanjutnya digunakan dalam menentukan model prediksi.

\section{4. Estimasi Parameter Copula dengan Kendall's Tau dan Spearman's Rho}

Setelah diperoleh nilai ukuran kebergantungan maka dapat dicari nilai parameter $\theta$ untuk setiap jenis copula. Parameter copula diestimasi untuk mengidentifikasi hubungan antar peubah. Hasil estimasi parameter copula tertampil pada Tabel 4.

Tabel 4. Penduga Parameter $\theta$ Copula dengan Kendall's Tau dan Spearman's Rho

\begin{tabular}{ccccc}
\hline \multicolumn{3}{c}{ Kendall's Tau $(\boldsymbol{\theta})$} & & Spearman's Rho $(\boldsymbol{\theta})$ \\
\hline $\begin{array}{c}\text { Clay- } \\
\text { ton }\end{array}$ & $\begin{array}{c}\text { Gum- } \\
\text { bel }\end{array}$ & Frank & AMH & Plackett \\
\hline $\mathbf{0 . 6 3 4}$ & 1.317 & 2.276 & 0.817 & 3.03078 \\
\hline
\end{tabular}




\section{5. Analisis Regresi Copula}

Penyelesaian solusi analisis regresi copula dilakukan dengan metode Monte Carlo. Percobaan angka random yang digunakan sebanyak 1000 percobaan angka random dengan distribusi data yang berbeda-beda. Dari ekspektasi bersyarat pada persamaan (13) diperoleh $\hat{y}_{i}$ yaitu

$$
\hat{y}_{i}=E_{v}\left[G^{-1}(v) c(u, v)\right]=\frac{1}{1000} \sum_{j=1}^{1000} G^{-1}\left(v_{j}\right) c\left(u_{j}, v_{j}\right)
$$

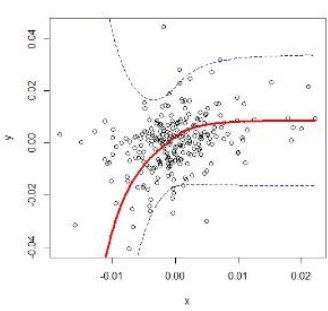

a. Model regresi copula Clayton dengan $x_{t} \sim$ Laplace dan $y_{t} \sim$ Normal

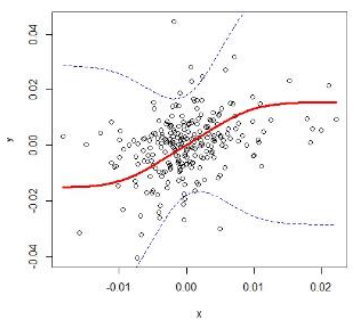

c. Model regresi copula Frank dengan $x_{t} \sim$ Normal dan $y_{t} \sim$ Laplace

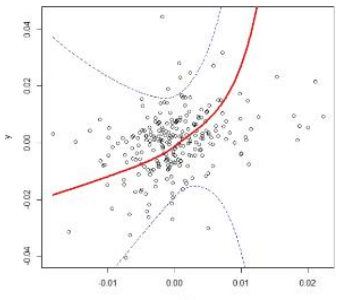

b. Model regresi copula Gumbel dengan $x_{t} \sim$ Laplace dan $y_{t} \sim$ Normal

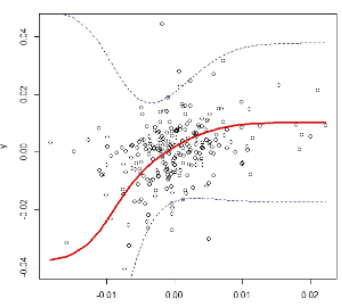

d. Model regresi copula AMH dengan $x_{t} \sim$ Normal dan $y_{t} \sim$ Normal

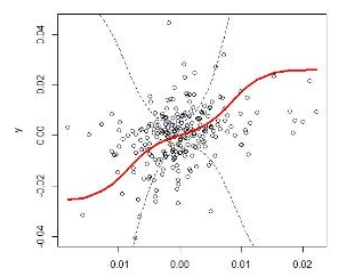

e. Model regresi copula Plackett dengan $x_{t} \sim$ Normal dan $y_{t} \sim$ Normal

Gambar 2. Model Regresi Copula untuk Setiap Alternatif Copula dengan Distribusi Marginal Tertentu.

Dari hasil perhitungan $\hat{y}_{i}$ diperoleh nilai prediksi untuk $y_{t}$, di mana hasil prediksi ini digunakan untuk menentukan model regresi copula terbaik berdasarkan ukuran error dari masing-masing model regresi. Selanjutnya model regresi terpilih digunakan untuk melakukan prediksi $y_{t}$ dengan data bagian II. Model regresi copula untuk setiap alternatif copula disajikan pada gambar 2.

Gambar 2 memperlihatkan hasil model regresi copula, dimana setiap copula sudah dilakukan kombinasi marginal. Namun hanya ditampilkan 5 gambar untuk setiap copula (Clayton, Frank, Gumbel, AMH, Plackett) dengan jenis distribusi yang sudah terpilih. Pada Gambar 2 dapat dilihat terdapat garis merah yang melintas, garis merah tersebut menunjukkan regresi copula.

\section{6. Estimasi Model Copula Berdasarkan Be- berapa Ukuran Error}

Menentukan model regresi copula yang digunakan sebagai model prediksi dilakukan berdasarkan nilai ketepatan prediksi dengan bantuan beberapa ukuran error. Pada paper ini digunakan empat jenis ukuran error yaitu MSE, ME, RMSE, dan MAE. Hasil perhitungan nilai error disajikan pada Tabel 5 .

Tabel 5. Nilai Error Regresi Copula untuk Setiap Alternatif Marginal dan Alternatif Copula

\begin{tabular}{|c|c|c|c|c|c|c|}
\hline Copula & $x_{t}$ & $y_{t}$ & MSE & $\mathrm{ME}$ & RMSE & MAE \\
\hline \multirow{9}{*}{$\begin{array}{l}\text { Clay- } \\
\text { ton }\end{array}$} & Laplace & Logis & 0.00068 & 0.00371 & 0.02601 & 0.01160 \\
\hline & Laplace & Laplace & 0.00079 & 0.00394 & 0.02804 & 0.01181 \\
\hline & Normal & Normal & 0.01399 & 0.01104 & 0.11829 & 0.01932 \\
\hline & Normal & Logis & 0.02100 & 0.01319 & 0.14492 & 0.02148 \\
\hline & Normal & Laplace & 0.02750 & 0.01494 & 0.16584 & 0.02322 \\
\hline & Logis & Normal & 0.00131 & 0.00441 & 0.03617 & 0.01255 \\
\hline & Logis & Logis & 0.00167 & 0.00488 & 0.04086 & 0.01302 \\
\hline & Logis & Laplace & 0.00205 & 0.00534 & 0.0453 & 0.01347 \\
\hline & Laplace & Normal & 0.00057 & 0.00349 & 0.02393 & 0.01137 \\
\hline \multirow{9}{*}{$\mathrm{AMH}$} & Laplace & Logis & 0.00014 & 0.00147 & 0.01203 & 0.00921 \\
\hline & Logis & Logis & 0.00014 & 0.00108 & 0.01189 & 0.00901 \\
\hline & Logis & Normal & 0.00014 & 0.00105 & 0.01187 & 0.00902 \\
\hline & Normal & Laplace & 0.00014 & 0.0009 & 0.01187 & 0.00886 \\
\hline & Normal & Normal & 0.00014 & 0.00083 & 0.01182 & 0.00891 \\
\hline & Laplace & Normal & 0.00014 & 0.00144 & 0.01202 & 0.00923 \\
\hline & Logis & Laplace & 0.00014 & 0.00111 & 0.01189 & 0.00896 \\
\hline & Normal & Logis & 0.00014 & 0.00086 & 0.01185 & 0.0089 \\
\hline & Laplace & Laplace & 0.00014 & 0.0015 & 0.01201 & 0.00915 \\
\hline \multirow{9}{*}{ Frank } & Logis & Laplace & 0.00012 & 0.00029 & 0.01088 & 0.0086 \\
\hline & Logis & Logis & 0.00012 & 0.00031 & 0.01096 & 0.00869 \\
\hline & Logis & Normal & 0.00012 & 0.00032 & 0.01102 & 0.00873 \\
\hline & Normal & Laplace & 0.00012 & 0.00025 & 0.01079 & 0.0085 \\
\hline & Normal & Logis & 0.00012 & 0.00026 & 0.01087 & 0.00858 \\
\hline & Normal & Normal & 0.00012 & 0.00027 & 0.01092 & 0.00863 \\
\hline & Laplace & Logis & 0.00012 & 0.0004 & 0.01117 & 0.00887 \\
\hline & Laplace & Normal & 0.00013 & 0.00042 & 0.01123 & 0.00893 \\
\hline & Laplace & Laplace & 0.00012 & 0.00038 & 0.01106 & 0.00878 \\
\hline \multirow{9}{*}{$\begin{array}{c}\text { Gum- } \\
\text { bel }\end{array}$} & Laplace & Laplace & 0.00507 & -0.0105 & 0.07118 & 0.01954 \\
\hline & Laplace & Logis & 0.00402 & -0.0094 & 0.06341 & 0.01844 \\
\hline & Laplace & Normal & 0.003 & -0.0014 & 0.05479 & 0.01712 \\
\hline & Logis & Logis & 0.01968 & -0.0197 & 0.14028 & 0.02874 \\
\hline & Logis & Laplace & 0.0257 & -0.0224 & 0.16031 & 0.03141 \\
\hline & Logis & Normal & 0.01351 & -0.0165 & 0.11622 & 0.02554 \\
\hline & Normal & Normal & 1.67034 & -0.1411 & 1.29242 & 0.15018 \\
\hline & Normal & Logis & 3.05631 & -0.1873 & 1.74823 & 0.19642 \\
\hline & Normal & Laplace & 4.27581 & -0.2204 & 2.0678 & 0.22943 \\
\hline \multirow{9}{*}{ Placket } & Logis & Laplace & 0.00013 & $4.8 \mathrm{E}-06$ & 0.01158 & 0.00895 \\
\hline & Logis & Normal & 0.00132 & 4.71E-05 & 0.0115 & 0.00892 \\
\hline & Normal & Logis & 0.00013 & $2.42 \mathrm{E}-\mathrm{O} 5$ & 0.01155 & 0.00887 \\
\hline & Normal & Normal & 0.00013 & $5.66 \mathrm{E}-06$ & 0.01149 & 0.00885 \\
\hline & Logis & Logis & 0.00013 & $3.14 \mathrm{E}-05$ & 0.01154 & 0.00894 \\
\hline & Normal & Laplace & 0.00013 & $4.72 \mathrm{E}-05$ & 0.01159 & 0.00888 \\
\hline & Laplace & Logis & 0.00013 & 0.00012 & 0.0116 & 0.00907 \\
\hline & Laplace & Normal & 0.00013 & 0.00014 & 0.01156 & 0.00906 \\
\hline & Laplace & Laplace & 0.00013 & $9.4 \mathrm{E}-05$ & 0.01162 & 0.00907 \\
\hline
\end{tabular}

Berdasarkan hasil perhitungan nilai error diperoleh bahwa model regresi copula terbaik adalah cop- 
ula Frank dengan distribusi marginal return IHSG adalah distribusi Laplace dan marginal return Kurs beli IDR-USD adalah distribusi Normal. Model regresi copula Frank tersebut terpilih menjadi yang terbaik berdasarkan dari error nilai prediksi terhadap data return IHSG yang bergantung pada return Kurs Beli IDR-USD relatif kecil dibandingkan dengan model regresi copula lain yang dibahas dalam paper ini. Model regresi copula terbaik yang memodelkan marginal $x_{t} \sim \operatorname{Normal}(\sigma=0.00601, \mu=0.00004)$ dan marginal $y_{t} \sim$ Laplace $(\lambda=128.11, \mu=0.00008)$ dengan fungsi distribusi, densitas, dan contour model tersebut disajikan pada Gambar 3 sedangkan model regresi copula Frank dengan $x_{t} \sim$ Normal dan $y_{t} \sim$ Laplace juga dapat dilihat pada Gambar 2c.

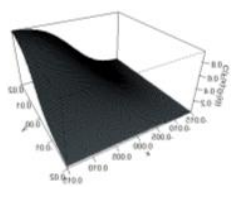

a. Fungsi Distribusi

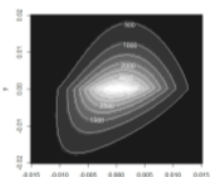

b. Contour Densitas

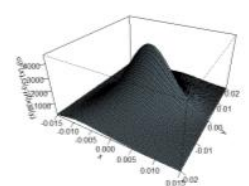

c. Fungsi Densitas

Gambar 3. Copula Frank dengan $x_{t}$ berdistribusi Normal ( $\sigma=0.00601, \mu=0.00004)$ dan $y_{t}$ berdistribusi Laplace $(\lambda=128.11, \mu=0.00008)$.

\section{7. Validasi Prediksi}

Model prediksi terpilih adalah model regresi copula Frank $x_{t} \sim$ Normal dan $y_{t} \sim$ Laplace. Model regresi ini digunakan dalam melakukan prediksi IHSG. Disini digunakan data bagian II untuk membangkitkan $\hat{y}$ yang kemudian divalidasi (dicocokkan) dengan data aktualnya. Line plot yang membandingkan data aktual dari IHSG dengan hasil prediksinya dapat dilihat pada Gambar 4.

Jika dilihat dari Gambar 4, hasil prediksi IHSG cukup mendekati data aktualnya, meskipun tidak semua data mempunyai hasil prediksi yang bagus. Selain itu dapat dilihat pula bahwa hasil dari prediksi sudah stasioner dimana nilainya mendekati suatu nilai

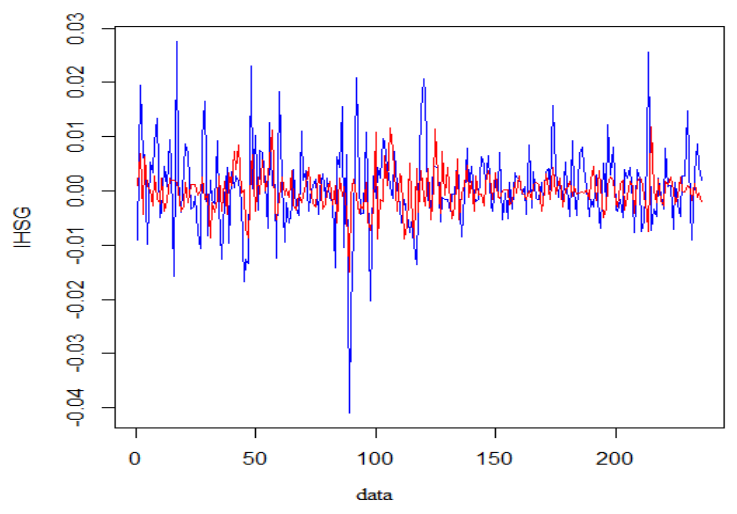

secara konstan

Gambar 4. Plot Deret Waktu IHSG aktual (biru) dan Prediksi (merah)
Selanjutnya untuk mengetahui ukuran kebaikan dari prediksi $(\hat{y})$ maka dihitung nilai error. Nilai error regresi copula terhadap data aktual dapat dilihat pada Tabel 6.

Tabel 6. Nilai Error Regresi Copula Terhadap Aktualnya.

\begin{tabular}{|c|c|c|c|c|}
\cline { 2 - 5 } \multicolumn{1}{c|}{} & MSE & ME & RMSE & MAE \\
\hline$\hat{y}$ & 0.00006553 & 0.0006453 & 0.0080956 & 0.0060477 \\
\hline
\end{tabular}

\section{KESIMPULAN}

Paper ini bertujuan untuk memperoleh model prediksi IHSG berdasarkan kurs beli IDR-USD melalui regresi copula dan memperoleh analisis prediksi IHSG berdasarkan kurs beli IDR-USD. Dari paper ini, kedua tujuan paper ini telah tercapai. Pertama, telah diperoleh model prediksi IHSG berdasarkan kurs beli IDR-USD yang melibatkan copula Frank dengan marginal $x_{t} \sim$ Normal $(\sigma=0.00601, \mu=0.00004)$ dan marginal $\quad y_{t} \sim$ Laplace $(\lambda=128.11, \mu=0.00008)$. Pemodelan melibatkan copula sehingga model-model distribusi marginal semakin banyak pilihan (bervarias) sesuai dengan kombinasi marginal yang dilakukan. Pada paper ini data return kurs beli IDR-USD dan IHSG mempunyai ukuran kebergantungan yang dinyatakan oleh Kendall's tau sebesar 0.2408797 dan Spearman's rho sebesar 0.3550996 sehingga dapat dinyatakan bahwa hubungan antar marginal positif. Kedua berdasarkan dari model prediksi yang dilakukan diperoleh model regresi terbaik, dari model regresi inilah kemudian dapat dilakukan prediksi terhadap IHSG. Hasil prediksi menunjukkan plot deret waktu yang dapat dilihat pada Gambar 4, terlihat bahwa hasil prediksi mempunyai perbandingan nilai yang baik dan mendekati data aktualnya meskipun tidak semua hasil prediksi sesuai dengan data aktualnya.

\section{DAFTAR PUSTAKA}

[1] I. Z. Alwi, Pasar Modal: Teori dan Aplikasi. Edisi Pertama, Yayasan Pancur Sawah: Adiniasri, 2003.

[2] Darwis, "Analisis Hubungan dan Prediksi Indeks Harga Saham Gabungan dengan Faktor Makroekonomi Melalui Pendekatan Copula," tesis, Program Pascasarjana Magister Sains, Institut Pertanian Bogor, Bogor, 2016.

[3] Octavina, "Model Prediksi Berbasis Copula," skripsi, Institut Teknologi Bandung, Bandung, 2012.

[4] R. B. Nelsen, An Introduction to Copulas, New York: Springer Series in Statistics, 2006.

[5] W. R. Blischke, M. R. Karim dan D. N. P. Murthy, Warranty Data Collection and Analysis, Spring Series in Reliability Engineering, London, 2011.

[6] L. R. Sasongko, "Copula untuk Memodelkan Kegagalan Dua Dimensi pada Produk Bergaransi dengan Strategi Penggantian," M.Si. tesis, Program Pascasarjana Magister Aktuaria, Institut Teknologi Bandung, Bandung, 2014. 
[7] A. Shemyakin dan A. Kniazev, Introduction to Bayesian Estimation and Copula Models of Dependence, John Wiley \& Sons, Inc, USA, 2017.

[8] L. W. Solikha, "Studi Copula Frank Family 2-Dimensi Dalam Indetifikasi struktur Dependensi," S.Si. skripsi, Fakultas Sains dan Teknologi, Universitas Islam Negeri Maulana Malik Ibrahim, Malang, 2012.

[9] N. Balakrishna dan C. D. Lai, Continous Bivariate Distribution, Springer, New York, 2009.

[10] M. Wang dan K. Rennolls, Bivariate Distribution Modelling with Tree Diameter and Height Data, Forest Science, 53(1), 16-24.

[11] D. B. Nugroho, "Metode Numerik", unpublished.

\section{Lampiran A. Fungsi Distribusi Univariat}

Berikut ini fungsi distribusi univariat yang digunakan dan dituliskan dalam paper ini. Misalkan $X$ adalah peubah acak kontinu dengan fungsi distribusi $F_{X}$.

1. Logistik, $X \sim \operatorname{Logistik}(\mu, \sigma)$.

$$
F_{X}(x)=\frac{1}{1+\exp (-z)}, \quad x \in(-\infty, \infty)
$$

$$
\text { dimana } z \equiv \frac{x-\mu}{\sigma}
$$

2. Laplace, $X \sim \operatorname{Logistik}(\mu, \lambda)$.

$$
F_{X}(x)=\left\{\begin{array}{ll}
\frac{1}{2} \exp (-\lambda(\mu-x)) & x \leq \mu \\
1-\frac{1}{2} \exp (-\lambda(\mu-x)) & x>\mu
\end{array}, x \in(-\infty, \infty)\right.
$$

3. Normal, $X \sim N\left(\mu, \sigma^{2}\right)$.

$$
F_{X}(x)=\frac{1}{x \sigma \sqrt{2 \pi}} \int_{-\infty}^{x} \exp \left\{-\frac{1}{2}\left(\frac{\ln t-\mu}{\sigma}\right)^{2}\right\} d t, x \in[0, \infty)
$$

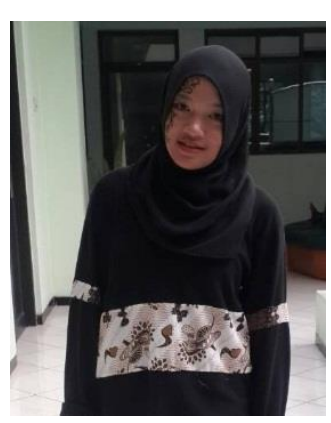

\begin{abstract}
Nia Lestari Arisandi
(662014014@student.uksw.edu) lahir dan tinggal di Bandungan, Kab. Semarang. Dia saat ini masih menempuh pendidikan tinggi di Program Studi Matematika, Fakultas Sains dan Matematika, Universitas Kristen Satya Wacana (UKSW) Salatiga. Tahun 2018 adalah tahun terakhir ia menempuh studi. Makalah ini merupakan hasil penelitian skripsinya yang dipublikasikan.
\end{abstract}

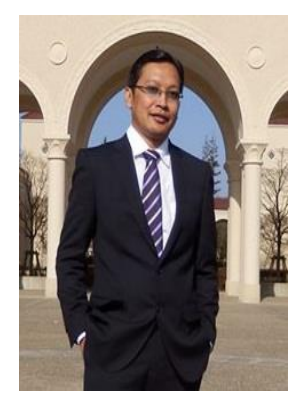

\section{Didit Budi Nugroho}

(didit.budinugroho@staff.uksw.edu) lahir pada tanggal 12 Februari 1977 di Yogyakarta, Ia adalah dosen Matematika di Fakultas Sains dan Matematika, Universitas Kristen Satya Wacana, sejak Agustus 2001 setelah lulus dari program studi Matematika S-1 di FMIPA UGM pad Februari 2001. Pada Juli 2008, berhasil menyelesaikan studi lanjut S-2 bidang keahlian Matematika Keuangan di FMIPA ITB, dan sudah menyelesaikan studi S-3 di Kwansei Gakuin University, Jepang pada tahun 2014. Mata Kuliah yang pernah diampu antara lain
Kalkulus Derivatif dan Integral, Persamaan Diferensial Biasa, Aljabar Linear, dan Metode Numeri. Beberapa buku yang telah dipublikasikan yaitu "Persamaan Diferensial Biasa dan Aplikasinya", "Kalkulus Integral dan Aplikasinya".

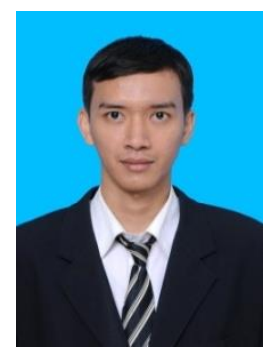

Leopoldus Ricky Sasongko (Leopoldus.sasongko@staff.uksw.edu) lahir di Ketapang, Kalimantan Barat, pada tanggal 14 November 1989. Pada tahun 2011, gelar Sarjana Sains (S.Si) diperoleh dari Universitas Kristen Satya Wacana (UKSW) Salatiga. Gelar Magister Sains (M.Si) didapat dari Program Pascasarjana Magister Aktuaria, Institut Teknologi Bandung (ITB), pada tahun 2014.

Ia bekerja di UKSW sejak tahun 2011 sebagai Calon Pengajar Akademik (Dosen) di Program Studi Matematika, Fakultas Sains dan Matematika, UKSW. Saat ini, ia menjadi Pengajar Akademik Tetap di UKSW.

Sasongko, M.Si, merupakan salah satu anggota Asosiasi Matematikawan Indonesia, IndoMS. Bidang penelitian yang digeluti adalah Matematika Aktuaria dan Garansi (Warranty). Salah satu makalah hasil penelitian adalah The Estimation of Renewal Functions Using the Mean Value Theorem for Integrals (MeVTI) Method yang terpublikasi di Jurnal Matematika dan Aplikasi deCartesiaN, Universitas Sam Ratulangi (UNSRAT). 